\title{
Microalgal biorefinery: Challenge and strategy in bioprocessing of microalgae carbohydrate for fine chemicals and biofuel
}

\author{
Tan Kean Meng ${ }^{1}$, Razif Harun², Ramizah Kamaludin ${ }^{1}$, Mohd Asyraf Kassim ${ }^{1 *}$ \\ ${ }^{1}$ Bioprocess Technology Division, School of Industrial Technology, Universiti Sains Malaysia (USM), Penang, Malaysia. \\ ${ }^{2}$ Department of Chemical and Environmental Engineering, Universiti Putra Malaysia, Serdang, Malaysia.
}

\begin{tabular}{l}
\hline ARTICLE INFO \\
\hline Article history: \\
Received on: Janurary 25, 2021 \\
Accepted on: July 23, 2021 \\
Available online: November 10, 2021 \\
\hline
\end{tabular}

Key words:

Carbohydrate, microalgal

biomass, pretreatment, hydrolysis, solvent

\begin{abstract}
Microalgal carbohydrate is one of the major macromolecule metabolites, which has recently gained great attention as an alternative feedstock for wide-range sustainable biobased products. These biopolymers can act as a chemical platform for the production of biofuels through a biochemical conversion process. However, low microalgal carbohydrate productivity at a large-scale production has become a major problem for economical biofuel production. Several strategies have been proposed and the approach only increased carbohydrate content but reduced the microalgal biomass production, resulting in low microalgal carbohydrate productivity. Besides, the inappropriate pretreatments and fermentation approaches specifically with high-energy techniques could cause an increase in the cost of biofuel production. This present review gives a comprehensive discussion on microalgal carbohydrate enhancement strategies via cultivation techniques including the influence of environmental stress on the microalgal biomass and carbohydrate productivity. This paper also reviews the state of art on downstream processing of microalgal biomass prior to the hydrolysis and fermentation process. The different fine chemicals such as bioethanol, biobutanol, and biohydrogen production from microalgal carbohydrate are also discussed. The information from this review provides a framework for bioconversion of microalgal carbohydrate for biofuel and fine chemicals. This production could be beneficial for potential industrial implementation.
\end{abstract}

\section{INTRODUCTION}

Recently, the interest in the production of fine chemicals and biofuel from algal biomass for partially replacing chemicals from petroleum-based feedstock has gained considerable worldwide attention. The utilization of microalgae biomass also exhibited more advantages over other types of renewable feedstock such as rice straw, plant trunk, leaf, and others. Microalgae contain less lignin and have a simple structure that is less recalcitrant compared to other types of renewable biomass. The other renewable biomass consists of complex biomass structure such as thick lignin, cellulose, and hemicellulose which could increase the difficulties of biofuel and fine chemical production [1]. Another advantage of these microalgae is that these microorganisms are microscopic

\footnotetext{
*Corresponding Author

Mohd Asyraf Kassim, Bioprocess Technology Division School of Industrial Technology, Universiti Sains Malaysia (USM), Penang, Malaysia. E-mail: asyrafkassim@usm.my
}

photosynthetic organisms that use sunlight and carbon dioxide $\left(\mathrm{CO}_{2}\right)$ as key regulators to conduct photosynthesis for their growth which can be integrated for $\mathrm{CO}_{2}$ biosequestration application. In addition, these microorganisms exhibit higher nutrient uptake, which accumulate in cell vacuoles and show a fast growth rate. This makes harvesting time between 1 and 10 days compared to terrestrial plants that require more than 3 months before the biomass can be harvested [2-4]. Moreover, the biomass produced during cultivation contains valuable chemical compounds including lipids, carbohydrates, and proteins. Generally, different types of microalgae strains will synthesize different biochemical metabolites, depending on the cell strains and cultivation condition. Table 1 summarizes the chemical composition distribution in different microalgae strains. Generally, all of these chemical compounds can be converted into other value-added products, such as animal feeds, bulk chemicals, and other bioactive compounds especially for the pharmaceutical industry (Fig. 1). 
Table 1: Chemical composition of different algal species on a dry matter basis (\%).

\begin{tabular}{|c|c|c|c|c|}
\hline Microalgae species & Protein $(\%)$ & Carbohydrate (\%) & Lipid (\%) & References \\
\hline Anabaena cylindrical & $43-56$ & $25-30$ & $4-7$ & {$[5]$} \\
\hline Aphanizomenon flosaquae & 62 & 23 & 3 & {$[6]$} \\
\hline Bellerochea sp. & 14.2 & 3.01 & 9.87 & [7] \\
\hline Botryococcus braunii (A) (UTEX-572) & 39.9 & 18.5 & 34.4 & {$[8]$} \\
\hline Chaetoceros sp. & 10.5 & 1.50 & 3.73 & [7] \\
\hline Chlamydomonas rheinhardii & 48 & 17 & 21 & {$[6]$} \\
\hline Chlorella pyrenoidosa & 57 & 26 & 2 & {$[5]$} \\
\hline Chlorella sp. & 6.07 & 7.09 & 1.82 & {$[7]$} \\
\hline Chlorella & 53.3 & 25.2 & 15.7 & [8] \\
\hline Chlorella vulgaris & 34.56 & 41.09 & 28.20 & [9] \\
\hline Dunaliella salina $\mathrm{V}-101$ & 23 & 20 & 10 & [10] \\
\hline Euglena gracilis & $39-61$ & $14-18$ & $14-20$ & {$[5]$} \\
\hline Nannochloropsis granulata (A) (CCMP-535) & 17.9 & 27.4 & 47.8 & {$[8]$} \\
\hline Neochloris oleoabundans (UTEX-1185 & 30.1 & 37.8 & 15.4 & {$[8]$} \\
\hline Phaeodactylum tricornutum & 36.67 & 46.78 & 1.07 & [11] \\
\hline Phaeodactylum tricornutum (CCMP-1327) & 39.6 & 25.2 & 18.6 & {$[8]$} \\
\hline Porphyridium aerugineum (UTEX-755) & 31.6 & 45.8 & 13.7 & {$[8]$} \\
\hline Rhodomonas sp. & 44.9 & 8.60 & 39.2 & [7] \\
\hline Scenedesmus dimorphus & $8-18$ & $21-52$ & $16-40$ & [5] \\
\hline Scenedesmus obliquus & $50-56$ & $10-17$ & $12-14$ & {$[5]$} \\
\hline Spirulinaa & 55.8 & 22.2 & 14.2 & {$[8]$} \\
\hline Thalassiosira sp. & 73.1 & 51.4 & 39.6 & [7] \\
\hline Tetraselmis chuii (PLY-429) & 46.5 & 25.0 & 12.3 & [8] \\
\hline
\end{tabular}

The potential of high value-added products synthesized from microalgal biomass is totally dependent on the chemical composition within the microalgae. For instance, microalgae with a high lipid content can be converted into biodiesel. Extracted carbohydrates from microalgal cells can be converted into bioethanol or biobutanol. Furthermore, the low lignin properties in microalgae exhibit an exceptional potential to be used as liquid biofuel feedstock due to the lower harsh pretreatment process. However, to date, researchers are still facing several obstacles that impede the development of the microalgal biorefinery process. The obstacles include a long cultivation period of microalgae to reach the mature state or stationary phase. Low microalgal biomass production, insufficient macromolecule accumulation, immature harvesting technology, pretreatment, and low product yield after the fermentation process could affect the feasibility of the biorefinery process. This comprehensive review discussed current trends and challenges of cultivation conditions and their downstream processing including pretreatment processes, hydrolysis methods, and fermentation conditions that could contribute to the formation of high value-added products. A critical approach was suggested at the end of the review. The focus was more on the strategy for improving carbohydrate accumulation in microalgal biomass. This was to ensure economic feasibility in the biorefinery process for the production of biofuels and fine chemicals.

\section{MICROALGAL CARBOHYDRATE BIOREFINERY}

Microalgal biorefinery is the process of synthesizing biofuel and fine chemicals using technology transformation from a single raw material. Chew et al. [12] agreed that this microalgal biorefinery is one of the current approaches that separate biochemical compounds in microalgal biomass into different fractions without damaging other fractions. Generally, the microalgal biomass harvested from cultivation contains three main chemical compounds: lipids, proteins, and carbohydrates [13]. As shown in Figure 2, it is known that each of these compounds has a significant value for a wide range of industries. All these biochemical compounds could be produced through different biochemical pathways.

\section{MICROALGAL CARBOHYDRATE}

The growth of microalgae and carbohydrate accumulation are typically related to the photosynthesis reaction in microalgal cells [14]. During photosynthesis, microalgae require $\mathrm{CO}_{2}$, sunlight, and oxygen $\left(\mathrm{O}_{2}\right)$ with the presence of water $\left(\mathrm{H}_{2} \mathrm{O}\right)$. These elements are needed to produce carbohydrate $\left(\mathrm{C}_{6} \mathrm{H}_{12} \mathrm{O}_{6}\right)$ and biomass as the final photosynthesis products. The overall photosynthesis reaction described by Meyer [15] is shown in Equation (1):

$$
6 \mathrm{CO}_{2}+12 \mathrm{H}_{2} \mathrm{O} \rightarrow \mathrm{C}_{6} \mathrm{H}_{12} \mathrm{O}_{6}+6 \mathrm{O}_{2}+6 \mathrm{H}_{2} \mathrm{O}
$$




\section{Microalgal biorefinery: Challenge and strategy in bioprocessing of microalgae carbohydrate for fine chemicals and biofuel, was "Graphical Abstract".}
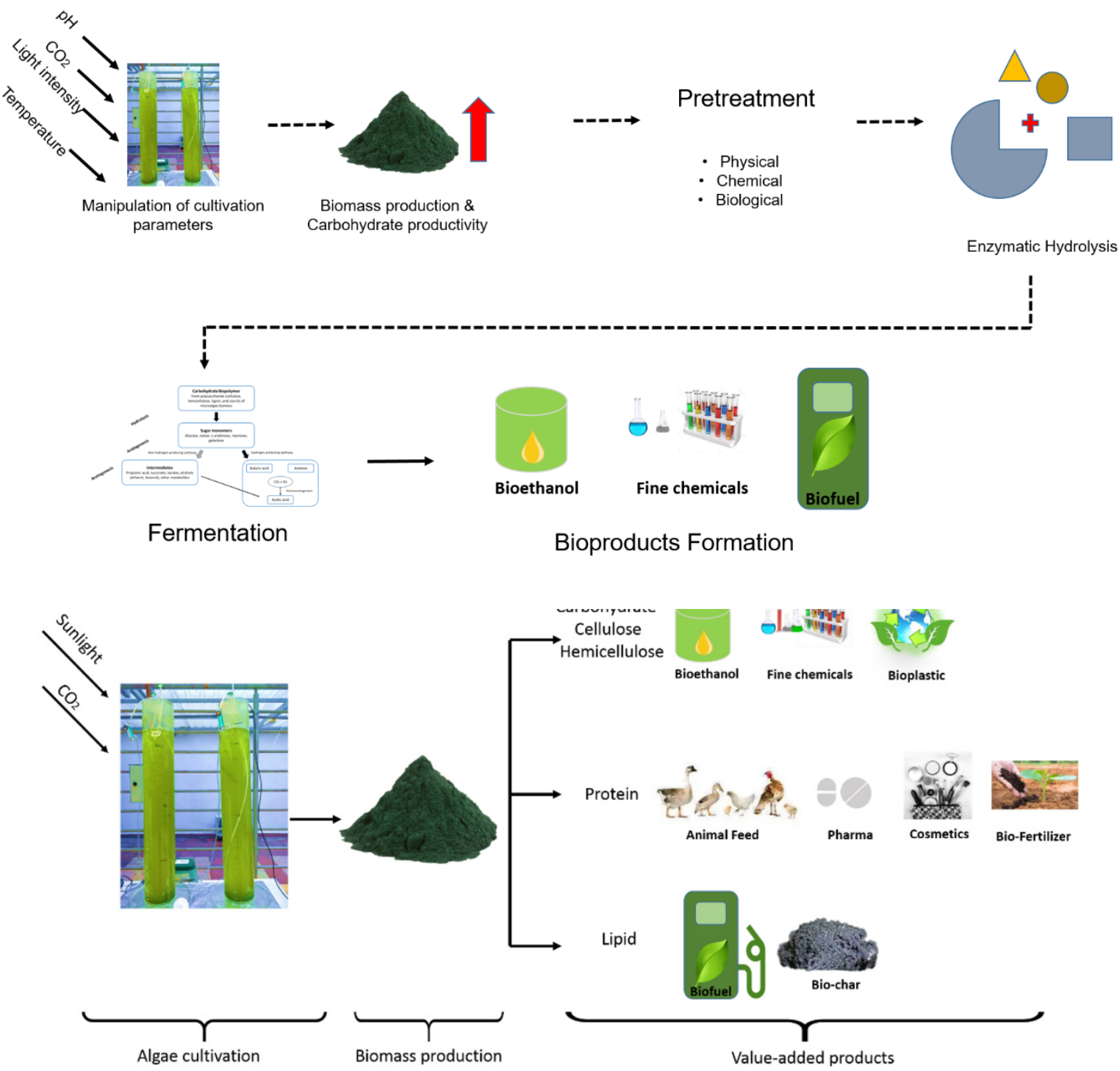

Figure 1: Various value-added produced from microalgae biomass.

Microalgal carbohydrates are one of the main products produced from microalgal photosynthesis and the carbohydrates can be in various forms. This macromolecule may be in various forms of monomers (i.e., monosaccharides) or polymers (i.e., di-, oligo-, and polysaccharides), depending on the microalgae species. Typically, the polysaccharides found in cyanobacteria and green or red algae are glycogen-type and starch-type polysaccharides, while $\beta$-glucan polysaccharides are mainly present in brown algae and diatoms [16]. These formations of polysaccharides in microalgae are of significance for the main structure of the cell wall and energy storage component and act as a food supply for the microalgae cell.

\section{CARBOHYDRATE METABOLISM}

The accumulation of carbohydrates in microalgae cells involves several main metabolite pathways. Among the pathways involved are glycolysis/gluconeogenesis, citrate cycle, pentose phosphate pathway (PPP), pentose and glucuronate interconversion, starch and sucrose metabolism have been proved that can enhance the carbohydrate biosynthesis in microalgae. All these pathways are important in terms of the contribution to carbohydrate accumulation in microalgal biomass. Figure 3 describes the formation of carbohydrates involving the targeted genes or enzymes and metabolites in microalgae. The enzymes such as $\alpha$-amylase, isoamylase, pullulanase, $\beta$-amylase, and glucoamylase 


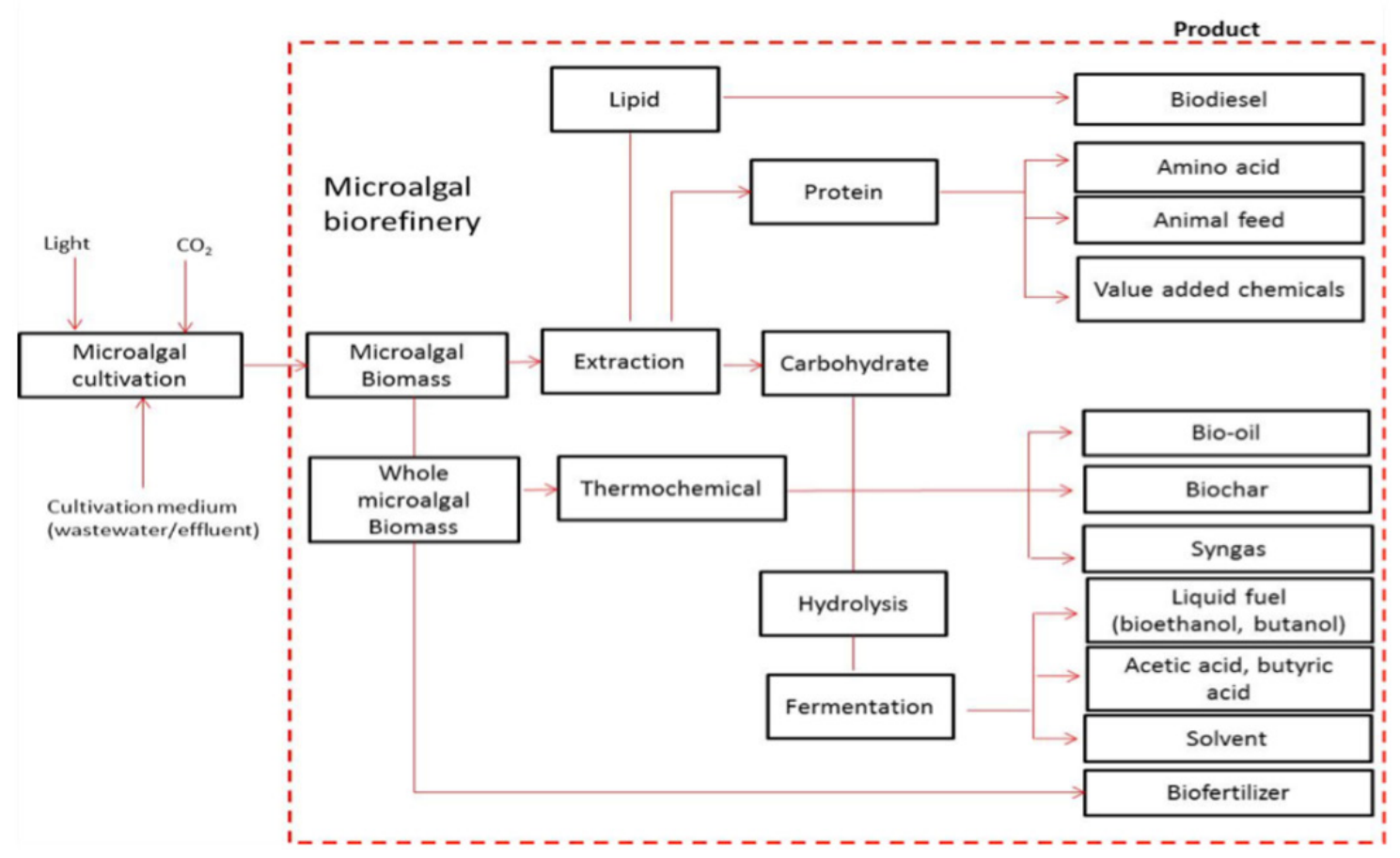

Figure 2: Microalgal technology and conversion process for the microalgal biorefinery.

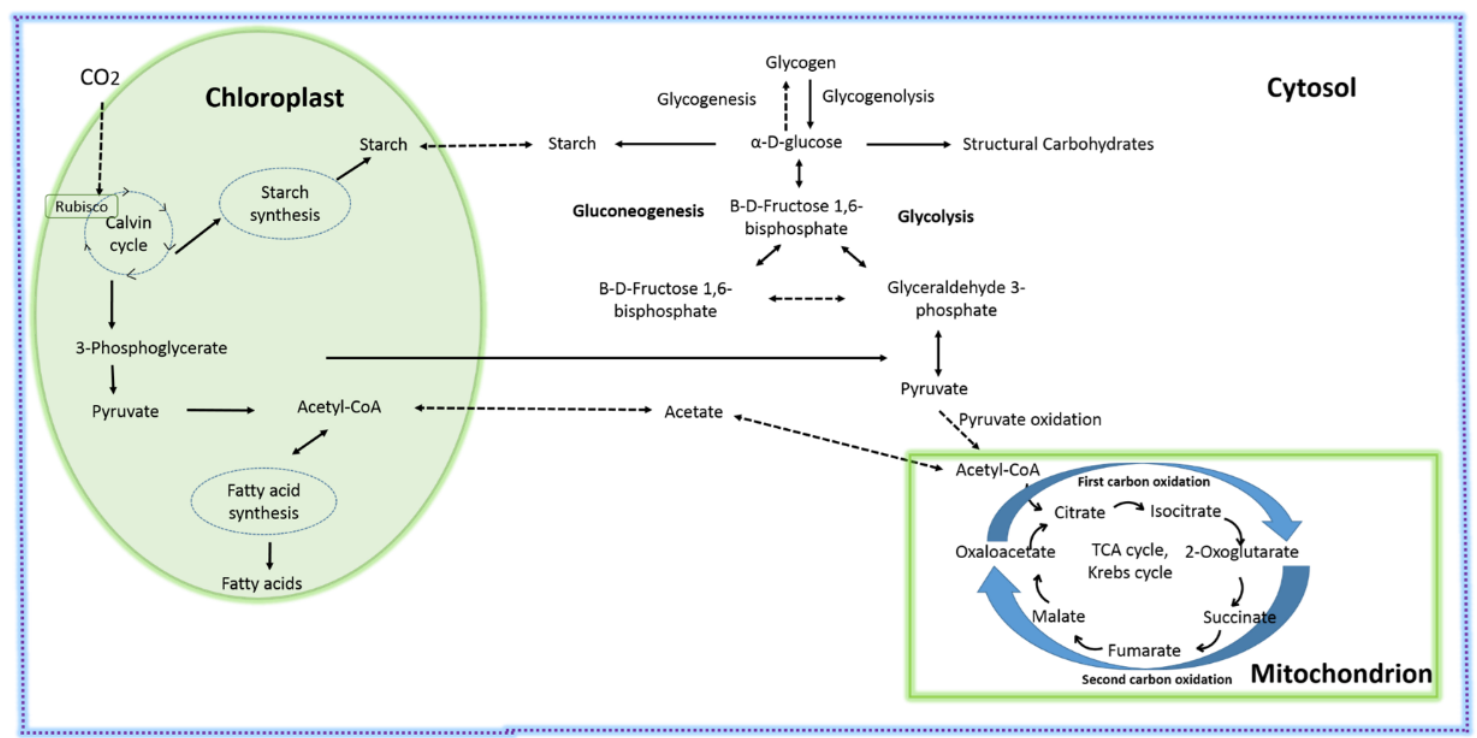

Figure 3: Carbohydrate biosynthesis pathway in microalgae.

were among the important enzymes that have been reported that play an important role in the carbohydrate biosynthesis in microalgae [17].

According to the study by Kuchitsu et al. [18], the starch biosynthesis in Chlamydomonas reinhardtii was largely affected by the starch synthesis pathway. This can particularly be seen in the especially adenosine diphosphate-glucose-starch (ADPglucose-starch) synthase enzyme under $\mathrm{CO}_{2}$-rich conditions. The importance of this synthase enzyme was further discussed by Patron and Keeling [19], who reported that this enzyme could enhance the synthesis of plastidic starch, which occurred in the plastid of green microalgae. Subsequently, the study also indicated that the formation of carbohydrates through the starch synthesis pathway was intercorrelated with the glycogen synthesis pathway. Other studies have also indicated the importance of the EmbdenMeyerhof pathway and the PPP in converting glucose into disaccharides and polysaccharides, mainly sucrose and starch [20]. Both pathways are notable in microalgal carbohydrate metabolism 
which has been shown to be responsible for glucose accumulation under light and dark conditions, respectively.

\section{STRATEGY TO IMPROVE MICROALGAL CARBOHYDRATE ACCUMULATION}

Carbohydrate biosynthesis in microalgal cells can be influenced by several factors. One of the most common factors that contributed to microalgal carbohydrate production is the surrounding cultivation conditions (i.e., abiotic factors). It is essential to determine the optimum cultivation conditions, favorable or merely tolerable for the growth of microalgal species. Cultivation under unfavorable conditions could either increase or decrease the microalgal growth and carbohydrate content $[21,22]$. The most common cultivation conditions such as the surrounding temperatures, light intensity, $\mathrm{pH}$, and $\mathrm{CO}_{2}$ concentration have reported that these cultivation parameters can significantly influence the microalgal growth and carbohydrate accumulation in microalgal biomass during cultivation [23]. These stress conditions applied toward microalgae have been proven as suitable approaches to enhance microalgal carbohydrate biosynthesis within an appropriate cultivation period and the detailed discussion is explained in the subsequent sections (Fig. 4).

\subsection{Cultivation Parameters}

\subsubsection{Effect of the interaction between $\mathrm{pH}$ and $\mathrm{CO}_{2}$ concentration}

Initial $\mathrm{pH}$ values are an essential parameter that can affect microalgal metabolism and carbohydrate formation in microalgal cells. The optimum $\mathrm{pH}$ value range for microalgae is generally between $\mathrm{pH}$
6 and 9 and generally depending on the type of microalgal species. Cultivation of microalgae under the upper $\mathrm{pH}$ limit will suppress cell growth by reducing the affinity of microalgae toward the free $\mathrm{CO}_{2}$. This will subsequently lead to a decrease in microalgae photosynthesis rate and growth rate [24,25], whereas the lower limit of $\mathrm{pH}$ will induce the acidic environment which could alter the nutrient uptake or stimulate metal toxicity, thus affecting the microalgae growth [26]. The maintaining of the surrounding $\mathrm{pH}$ is important to achieve a continued active photosynthesis process under natural daylight [27]. However, the fluctuation of $\mathrm{pH}$ values can happen essentially during cultivation especially in the presence of $\mathrm{CO}_{2}$. This phenomenon is due to the presence of $\mathrm{CO}_{2}$ in the cultivation medium that could react with $\mathrm{H}_{2} \mathrm{O}$ and produce carbonic acid $\left(\mathrm{H}_{2} \mathrm{CO}_{3}\right)$ [28]. Subsequently, $\mathrm{H}_{2} \mathrm{CO}_{3}$ decreases the $\mathrm{pH}$ value of the cultivation medium to a certain level. This may influence the nutrient uptake and enzyme kinetics involved in microalgal metabolism $[29,30]$.

It was known that the addition of $\mathrm{CO}_{2}$ to the cultivation medium could enhance the microalgae biomass growth and affect the biomass compositions especially carbohydrate and lipid content in the microalgae cell [31]. Maintaining the $\mathrm{pH}$ value in the cultivation medium in a photobioreactor using the $\mathrm{CO}_{2}$ manipulation could increase the microalgae productivity and lipid accumulation in the microalgae [32]. The interaction between $\mathrm{pH}$ and $\mathrm{CO}_{2}$ concentration has been proved on Nannochloropsis sp. MASCC 11 which exhibited excellent growth and lipid production up to 108.2 and $782.7 \mathrm{mg} \mathrm{l}^{-1}$ on $\mathrm{pH} 6.00$ and $5 \% \mathrm{CO}_{2}$ concentration, respectively [33]. The supplementation of $\mathrm{CO}_{2}$ through aeration toward the microalgae culture did not only involve the lipid fraction, while it

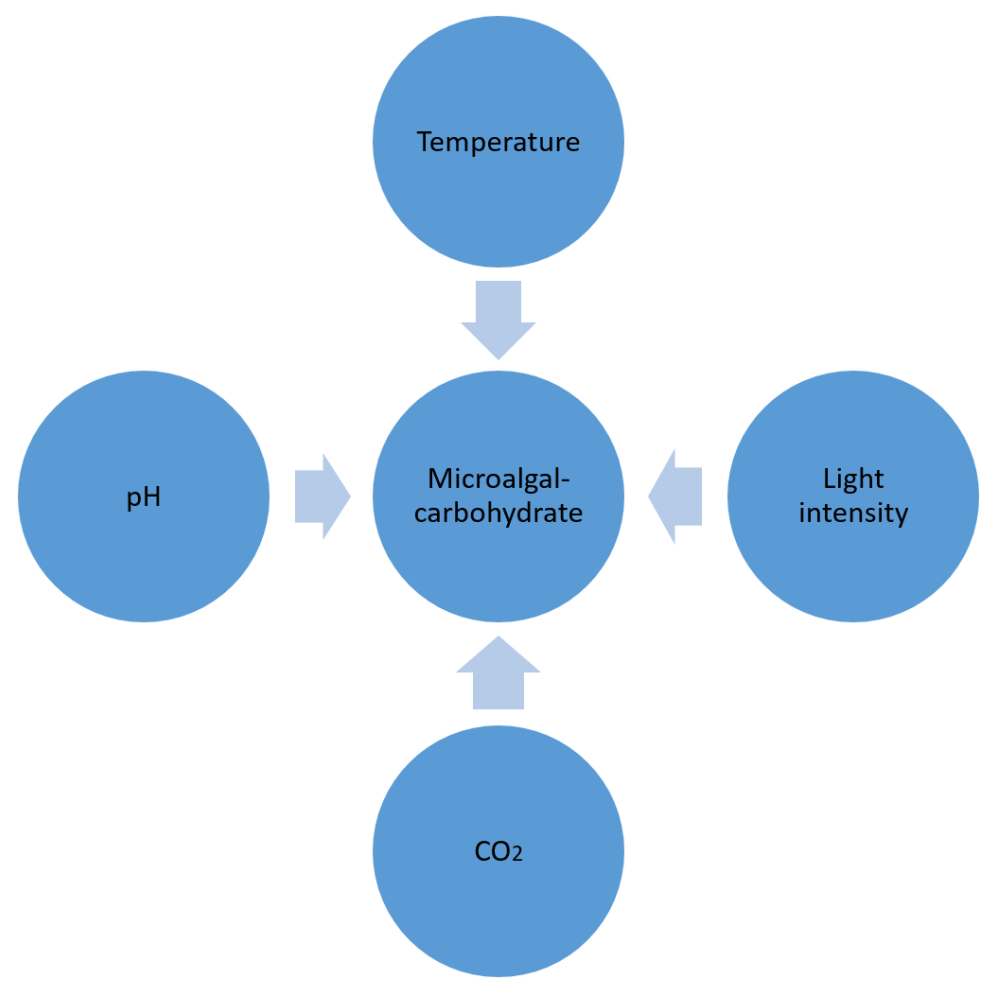

Figure 4: The summary diagram impact of different stress factors on the microalgal carbohydrate. 
also involved the carbohydrate fraction in the microalgae biomass through the carbohydrate metabolism pathway. The previous study showed that the increase in the $\mathrm{CO}_{2}$ concentration up to $25 \% \mathrm{CO}_{2}$ concentration (v/v) along the microalgae cultivation was increased gradually on the growth rate and carbohydrate content in the Scenedesmus bajacalifornicus BBKLP -07 strain. This increment of both growth rate and carbohydrate content was recorded as $0.16 \pm 0.0012 \mathrm{~d}^{-1}$ and $26.19 \%$, respectively, compared to the control treatment $\left(0.04 \% \mathrm{CO}_{2}\right)$ [34]. This was due to the fact that $\mathrm{CO}_{2}$ could act as an inorganic carbon source for triggering the microalgae growth and carbon flux flow for carbohydrate synthesis through the photosynthesis process [35].

Providing the $\mathrm{CO}_{2}$ toward the microalgae during cultivation has been proved to be a good strategy to improve the microalgae growth rate and biochemical accumulation inside the microalgae body [36,37]. However, further increasing the $\mathrm{CO}_{2}$ supplement toward microalgae will lead to a decrease in the cultivation $\mathrm{pH}$ value. This phenomenon will result in an adverse effect on the microalgae growth and subsequently affect its biochemical composition accumulation. It can be observed that the cultivation of the Chlorella sp. under $30 \% \mathrm{CO}_{2}$ concentration (v/v) could reduce the specific growth rate of microalgae up to $76 \%$ compared under normal condition $0.04 \% \mathrm{CO}_{2}(\mathrm{v} / \mathrm{v})$ [38]. The increment of $\mathrm{CO}_{2}$ concentration beyond the microalgae susceptible limit not only limits the specific microalgae growth but also affects the carbohydrate accumulation in the cell biomass. There was an obvious decrease in carbohydrate composition in Chlorella sp. microalgae by $72.22 \%$ when the cultivation was conducted under $15 \%$ of $\mathrm{CO}_{2}(\mathrm{v} / \mathrm{v})$ concentration.

Under the high $\mathrm{CO}_{2}$ concentration (low $\mathrm{pH}$ condition), the microalgae were required to achieve a high-energy demand to drive the proton gradient across the membrane, to stabilize the intracellular $\mathrm{pH}$ condition. Then, this energy loss will decrease the photosynthesis rate and affect the carbohydrate accumulation process in microalgae cells [39]. The capability of microalgae in response to the high $\mathrm{CO}_{2}$ concentration is species-dependent [40]. The microalgae that can tolerate the $\mathrm{CO}_{2}$ concentration in between $2 \%$ and $5 \%(\mathrm{v} / \mathrm{v})$ are categorized as $\mathrm{CO}_{2}$-sensitive microalgae, while those that can tolerate between $5 \%$ and $20 \%(\mathrm{v} / \mathrm{v})$ are categorized as $\mathrm{CO}_{2}$-tolerant microalgae. From an industrial perspective, the microalgae that possess the most tolerant and robust characteristics are important to ensure sustainable microalgae bioprocessing and technologies. The robust microalgae strains that can grow under a wide range of $\mathrm{pH}$ and high $\mathrm{CO}_{2}$ concentrations are economically feasible for continuous production with low maintenance under large-scale production. Based on the summary above, it clearly indicated that microalgae have a great potential to become one of the $\mathrm{CO}_{2}$ capture and utilization agents. These microalgae can be cultivated in an integrated system with flue gas and the biomass produced can be used as feedstock for microalgae-based products in a biorefinery.

\subsubsection{Effect of temperature and light intensity}

Another factor that could significantly affect microalgal growth rate and carbohydrate accumulation is the combined effect of light intensity and surrounding temperature. Generally, microalgae cultivation under outdoor conditions could be significantly affected by the light intensity and the surrounding temperature. It is known that light intensity influences the photoadaptation/ photoacclimation and photoinhibition processes in microalgal cells. The majority of microalgae are light-saturated under light intensities of $200-400 \mu \mathrm{mol} \mathrm{m} \mathrm{m}^{-2} \mathrm{~s}^{-1}$. Under the low light intensity, the microalgae will exhibit a slow growth rate due to the inhibition of light harvesting pigments, chlorophyll a and $\mathrm{b}$ in that stage. However, the increase of the illuminated light intensity toward the microalgae over the certain threshold value will generate more heat which will raise the temperature. This will cause a decline in damage to the cell and the biochemical composition of microalgae [41].

Generally, the characteristic behavior of the microalgae toward light intensity and environmental temperature could be categorized as heat-sensitive and heat tolerance microalgae [42]. To date, most of the microalgae strains that are isolated nowadays could survive a wide range of light intensities and temperatures through acclimation or adaptation strategies within microalgae metabolism. This combination effect has been observed on Tetradesmus obliquus which performs well on $36^{\circ} \mathrm{C}$ with 434.75 mol m $\mathrm{m}^{-2} \mathrm{~s}^{-1}$. The $T$. obliquus obtained the maximum biomass production up to $115 \mathrm{mg} \mathrm{l}^{-1} \mathrm{~d}^{-1}$ under this condition [43]. However, other strains like Chlorella vulgaris exhibited the maximum cell growth up to $1.13 \pm 0.04$ day $^{-1}$ when the cultivation was performed under light exposure of $100 \mu \mathrm{mol} \mathrm{m} \mathrm{m}^{-2} \mathrm{~s}^{-1}$ and temperature of $25 \pm 0.5^{\circ} \mathrm{C}$ [44]. The optimum light intensity and temperature were observed differently from each microalgae strain. Further increased light intensity and surrounding temperature could lead to the effect of photoinhibition. This can be observed when the microalgae were exposed to an intensity of $94.50 \mu \mathrm{mol} \mathrm{m} \mathrm{m}^{-2} \mathrm{~s}^{-1}$ toward the heat-sensitive microalgae. Low microalgal biomass production was obtained due to the degradation of the D1 protein in the photosynthetic system II in the microalgae [45].

Apart from that, the effect of light intensity and surrounding temperature was also reported that could influence the carbohydrate content in microalgal biomass [46]. It is worth mentioning that, during microalgal photosynthesis, carbohydrates are produced as the final product to be used as an energy source during respiration. Leading to this, a previous study indicated that the optimum light intensity and temperature as $150 \mu \mathrm{mol} \mathrm{m} \mathrm{m}^{-2} \mathrm{~s}^{-1}$ and $26^{\circ} \mathrm{C}$ could increase carbohydrate content in Pavlova lutheri up to $66 \%$ compared to the normal condition [47]. Nevertheless, it was found that a further increase of light intensity beyond $400 \mu \mathrm{mol}$ $\mathrm{m}^{-2} \mathrm{~s}^{-1}$ appeared to reduce the carbohydrate content to $8 \%$ in this microalgae strain. The excessive exposure of light and surrounding temperature on microalgae most probably leads to the degradation of microalgal carbohydrates of which these biomolecules will be transformed into lipids in order to protect microalgal cells from photoinhibition [48].

Therefore, as per the discussion above, it is clearly indicated that the effect of light intensity and surrounding temperature toward microalgae is species-dependent. It is important to select the suitable light intensity and temperature to obtain the maximum biomass production and carbohydrate content in microalgae especially those cultivated under outdoor conditions. On the other 
hand, selecting the robust strain that is able to withstand a wide range of temperature and light intensity fluctuation with little or nonsignificant effect on growth and carbohydrate productivity is important especially for continuous outdoor cultivation.

\section{DOWNSTREAM PROCESSING OF MICROALGAL BIOMASS}

In order to produce biofuels and fine chemicals from microalgal carbohydrate through the biochemical pathway, several major steps such as biomass handling, pretreatment, hydrolysis, and fermentation are the important steps to ensure the economic feasibility of the end products' formation (Fig. 5). The details of each process are described in the next subtopics.

\subsection{Microalgal Biomass Pretreatment}

Microalgae are eukaryotic microorganisms that have a complex polymer cell wall structure. The structure of a complex polymer cell wall mainly consists of noncellulosic polysaccharides, such as rhamnose, galactose, glucuronic acid, and glucosamine, whereas glucose is only a minor component [49]. These components play an important role in the formation of dynamic and rigid microalgae cell structure that allows microalgae to sustain or maintain cell bodies in harsh conditions. The plasticity properties enable microalgae ells to expand into different shapes [1-6]. In order to extract polysaccharides or carbohydrates from intracellular microalgal cells for biofuels and fine chemical production, pretreatment is a vital step for the valorisation of breaking down this rigid microalgal cell wall structure prior to fermentation. Pretreatment provides accessibility for enzymatic hydrolysis and improves digestibility of polysaccharides or carbohydrates available in the biomass [50]. To date, several microalgal cell disruption and pretreatment methods have been introduced by previous researchers. These methods can be categorized into three techniques: physical, chemical, and biological (Table 2) [51,52].

A physical pretreatment normally involved the mechanical, heat, or both combination to reduce the particle sizes; chemical pretreatment usually used the acid or alkaline to break the hydrogen or ester bond in the cell membrane, whereas the biological pretreatment involved the utilization of microbes or enzymes to disintegrate the biomass and release the sugars for subsequent hydrolysis and fermentation process (Table 3 ).

To date, there are no specific pretreatment methods that can be applied for all types of microalgal strains. This limitation is due to the fact that some pretreatment methods are species-specific and significantly contributed by the cell structure and composition. An effective pretreatment method should be considered with the aspects of cost-effective, time-saving, energy-efficient, and simple to upscale for industrial application.

\subsection{Enzymatic Hydrolysis}

As mentioned earlier, hydrolysis is a major step involved in biofuel and fine chemical production via the bioconversion process. This ensures that all microalgae carbohydrates available in microalgal biomass cells are converted into monomer sugars prior to the fermentation process. The utilization of an enzyme for hydrolysis depended significantly on the microalgae cell wall composition, biochemical distribution, and microalgae structure. All these factors are varying from each of the microalgae species.

The most common enzymes used in this process are cellulase and amylase $[66,67]$. The cellulase and hemicellulase have been reported by previous studies and are also considered as the common enzymes used to extract sugar from microalgal biomass [68]. These two enzymes are used to hydrolyze the intracellular cellulose and hemicellulose cell wall structure in microalgal biomass and produce simple sugar for fermentation. Investigations on the enzymatic hydrolysis of microalgal biomass, such as Chlorella sp., Scenedesmus sp., Nannochloropsis gaditana, and Tetraselmis suecica, for enhancing fermentation products have been indicated in earlier research [69-71]. Studies have indicated that the hydrolyzed microalgal biomass could significantly increase the yield of final fermentation products.

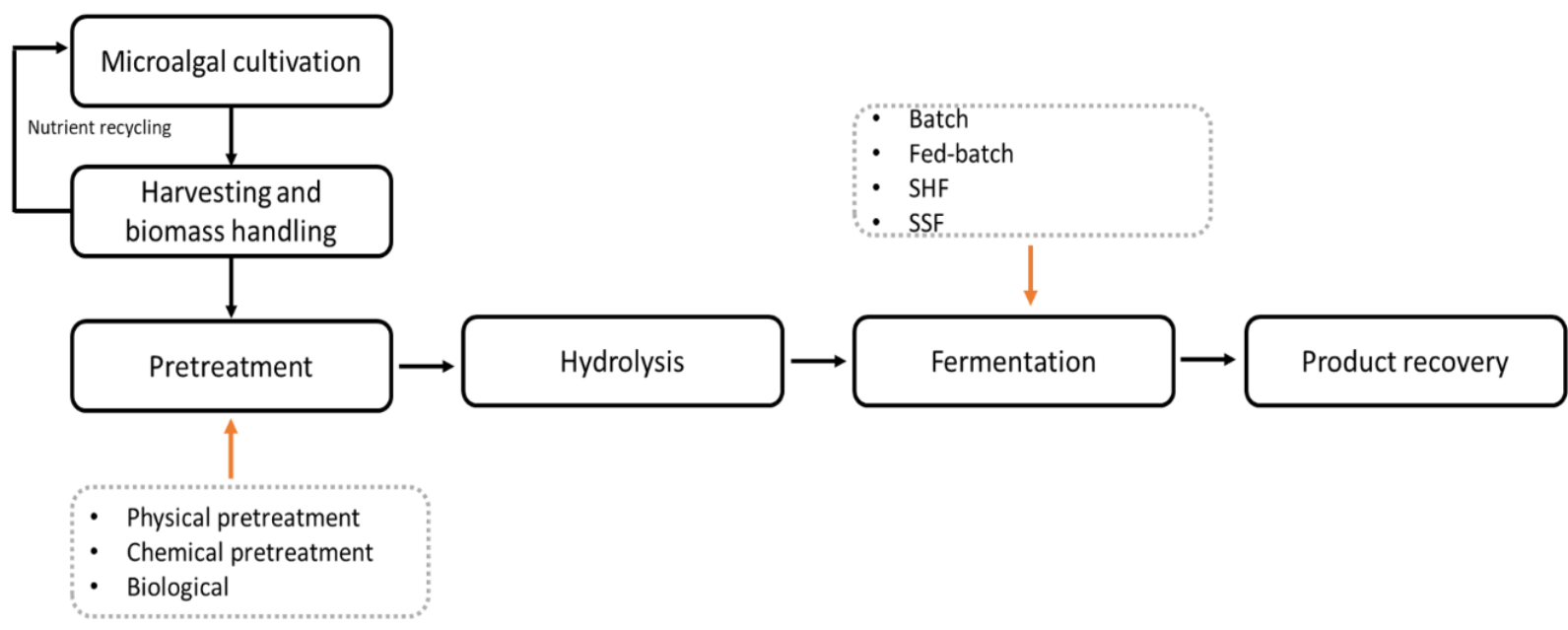

Figure 5: Process for liquid fuel and chemicals from the fermentation of microalgal carbohydrate. 
Table 2: Types of pretreatment, advantages and limitations used to pretreat the microalgal biomass.

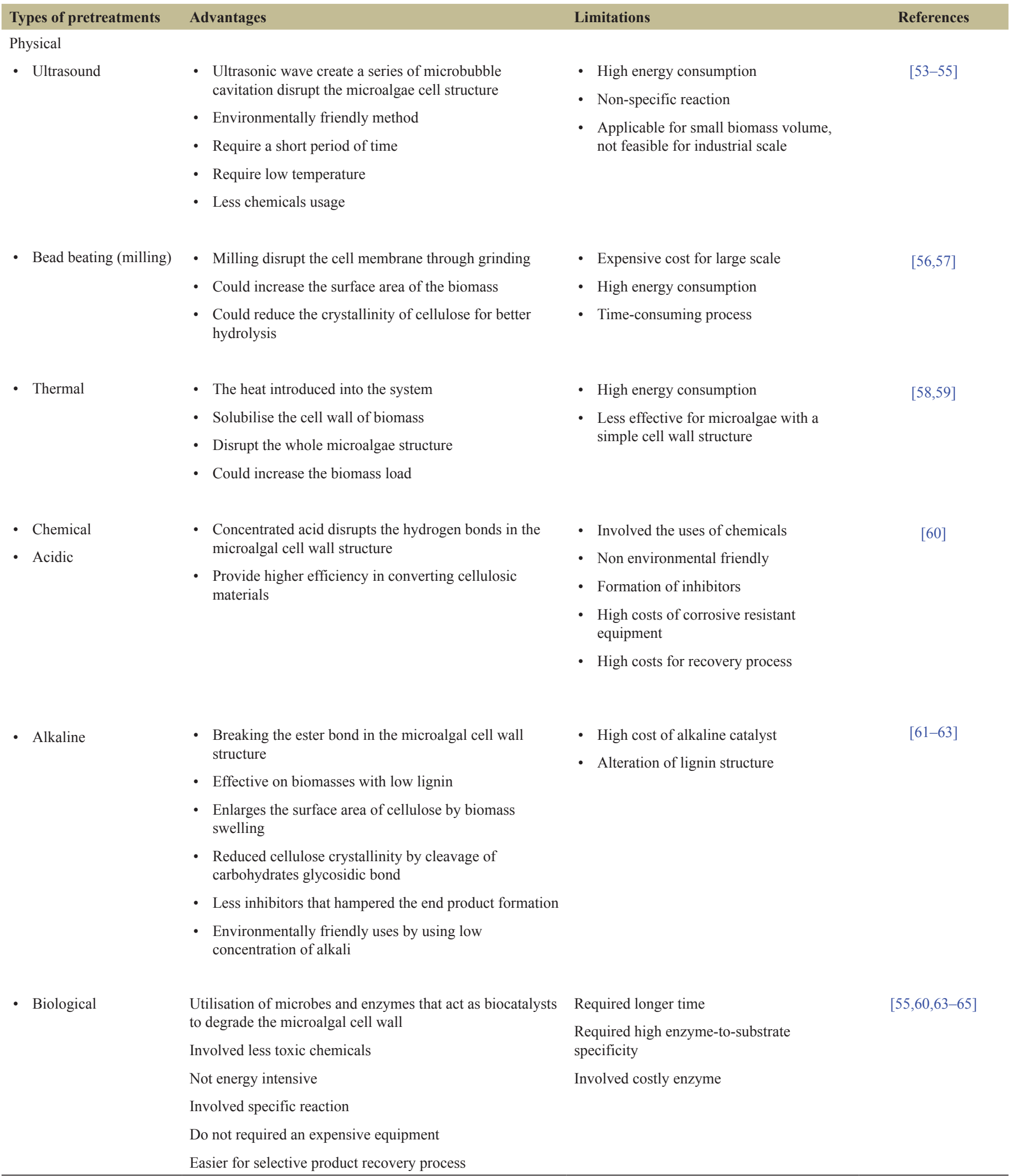


Table 3: The process condition and sugar production based on different microalgal biomass.

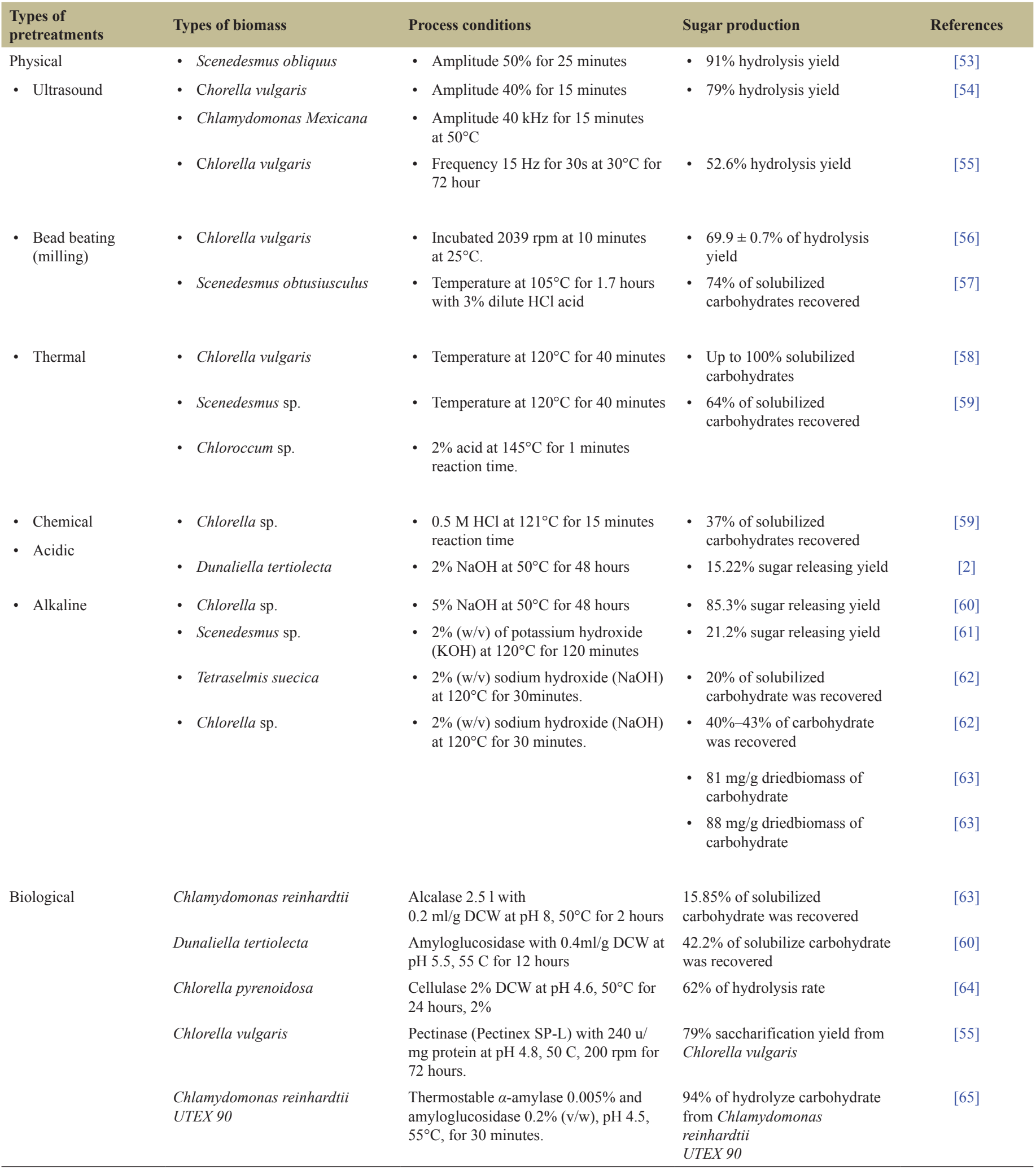


Theoretically, the efficiency of enzymatic hydrolysis of microalgal biomass depends significantly on various hydrolysis parameters, including temperature, $\mathrm{pH}$, enzyme loading, and biomass concentration $[67,72]$. Selecting the optimum hydrolysis process is important to achieve the maximum sugar recovery from microalgae biomass. A study found that the maximum reducing sugars were obtained at optimum conditions for the hydrolysis of C. reinhardtii using $0.2 \%$ glucoamylase at $55^{\circ} \mathrm{C}$ and $\mathrm{pH} 4.5$. Enzymatic hydrolysis of microalgal biomass beyond optimal conditions will result in low reducing sugar concentrations. In another study, the optimum enzymatic hydrolysis condition produced maximum sugars at $64 \%$ hydrolysis yield from $C$. humicola from the hydrolysis process using $10 \mathrm{~g}^{-1}$ biomass at $40^{\circ} \mathrm{C}$ and an initial $\mathrm{pH}$ of 4.8 [73]. Such parameter conditions have been identified as one of the major bottlenecks ensuring the feasibility of sugar production from microalgal biomass. Thus, further research and development are needed to improve enzymatic hydrolysis under high biomass concentrations.

\subsection{Fermentation of Microalgal Carbohydrate}

\subsubsection{Bioethanol}

Liquid biofuels have commonly derived from microalgal biomass is bioethanol. This product is produced from anaerobic fermentation using microorganisms, such as yeast or bacteria as the biocatalyst. Theoretically, the maximum yield of carbohydrate fermentation is $0.51 \mathrm{~kg}$ ethanol and $0.49 \mathrm{~kg} \mathrm{CO}$ per $\mathrm{kg}$ of sugar. In general, the simplified reaction equation for ethanol production is as follows:

$$
\begin{aligned}
& \mathrm{C}_{6} \mathrm{H}_{12} \mathrm{O}_{6} \rightarrow 2 \mathrm{CH}_{3} \mathrm{CH}_{2} \mathrm{OH}+2 \mathrm{CO}_{2} \\
& \text { Glucose Ethanol Carbon dioxide }
\end{aligned}
$$

The study on the potential of microalgal carbohydrate as bioethanol feedstock using Saccharomyces cerevisiae has been widely reported [74-76]. The fermentation of acid-treated $C$. vulgaris FSP-E containing 51\% carbohydrate per dry weight biomass produced $11.7 \mathrm{~g}^{-1}$ of bioethanol that corresponded to $87.6 \%$ ethanol yield [74]. Similar observations were reported on the fermentation of $C$. reinhardtii biomass has been reported that fermented from this biomass produced $235 \mathrm{mg}$ of ethanol from the fermentation of $1 \mathrm{~g}$ of biomass through separate hydrolysis and fermentation (SHF) analysis [72]. Another study indicated that the fermentation of nitric acid $\left(\mathrm{HNO}_{3}\right)$-treated microalgae Spirulina platensis produced $16.32 \%$ ethanol yield [74].

The fermentation of lipid-extracted microalgal biomass residual has also been explored as an alternative approach to reduce the accumulation of fermented by-products. According to Harun et al. [76], the fermentation of lipid-extracted Chlorococcum sp. produced $3.83 \mathrm{~g}$ ethanol/10 g microalgal biomass. This study showed that extracted lipid was converted into biodiesel, and the method provided a new approach for the microalgal biorefinery concept.

Successful ethanol production from microalgal carbohydrates could also be attributed to the fermentation mode used during the conversion process. Various fermentation modes have been proposed for ethanol fermentation, including SHF; simultaneous saccharification and fermentation (SSF); simultaneous saccharification cofermentation; and separate hydrolysis and cofermentation.

Danquah et al. [77] compared the fermentation of microalgal Chlorococcum sp. biomass in different fermentation modes and concluded that SHF gave the highest bioethanol yield. In contrast, a different observation was reported regarding the fermentation of Chlamydomonas mexicana in SHF and SSF modes. A higher ethanol yield of $10.5 \mathrm{~g} \mathrm{l}^{-1}$ was obtained from the fermentation of microalgal biomass generated from combined sonication and enzymatic hydrolysis in the SSF approach [75]. Increments in ethanol production based on the SSF approach could be explained as a method to provide better hydrolysis efficiency based on the cellulose activity for sugar production toward the biomass [78]. Table 4 shows the influence of the types of pretreatments, conditions, and yields of bioethanol production based on different microalgae strains. Based on this discussion, it can be concluded that not only does bioethanol production depend solely on the microalgal carbohydrate content, but also other factors such as pretreatment and fermentation modes are equally important to ensure the economic feasibility of the bioethanol production.

\subsubsection{Biobutanol}

Apart from bioethanol, biobutanol can also be used as an alternative biofuel for transportation. Chemically, biobutanol or butyl alcohol is a colorless liquid with four-carbon alcohols, molecular formula of $\mathrm{C}_{4} \mathrm{H}_{9} \mathrm{OH}$. This chemical compound has a distinct odor and is completely miscible with organic solvents and partly miscible with $\mathrm{H}_{2} \mathrm{O}$. Currently, butanol is used in various applications, which can be found in many chemical additives, solvents for perfume, and the manufacturing of antibiotics and as a chemical platform for other chemical syntheses [85]. Existing studies have indicated that this chemical compound can be used and blended up to $85 \%$ with gasoline with and without engine modification [86].

Biological biobutanol production via acetone-butanol-ethanol (ABE) fermentation using different ranges of feedstock including cellulosic and noncellulosic materials has been investigated globally. Biobutanol via the fermentation process has exhibited more advantages over the chemical reaction route. However, the production of biobutanol at the commercial stage faces several problems or challenges [87]. For example, ABE fermentation using cellulosic materials, such as empty fruit bunch (EFB), corn, sugarcane, and straw has been found to be relatively expensive. This may be due to the complicated technology used to overcome feedstock recalcitrance resulting from the presence of lignin in the biomass. Major issues associated with $\mathrm{ABE}$ fermentation at the commercial scale are food versus fuel found to be significant for sustainable economic production globally.

The production of biobutanol via fermentation using microalgal carbohydrates is a promising approach to overcome those issues, as this feedstock is simple and contains low lignin. It is also considered renewable and sustainable and contains a high concentration of carbohydrates. The potential of microalgae biomass as feedstock is highly positive and ensures feasible 
Table 4: The types of pretreatment, fermentation condition, and bioethanol yield based on different microalgae strains.

\begin{tabular}{|c|c|c|c|c|}
\hline Microalgae strain & Pretreatment & Condition (fermentation) & Bioethanol yield () & References \\
\hline Arthrospira (Spirulina) platensis & None & $500 \mathrm{rpm}$ and $30^{\circ} \mathrm{C}$ for 96 hours & 6.5 & {$[79]$} \\
\hline Chlorella sp. & $\begin{array}{l}\text { Chemical pretreatment } \\
\left(5 \% \mathrm{H}_{2} \mathrm{SO}_{4}\right)\end{array}$ & $150 \mathrm{rpm}$ and $32^{\circ} \mathrm{C}$ for 84 hours & 0.28 & [80] \\
\hline Mixed culture of microalgae & $\begin{array}{l}\text { Chemical pretreatment } \\
(0.03 \%(\mathrm{v} / \mathrm{v}) \mathrm{H} 2 \mathrm{SO} 4 \text { and } 2.5 \%(\mathrm{v} / \mathrm{v}) \\
\mathrm{MgSO} 4)\end{array}$ & $150 \mathrm{rpm}$ and $30^{\circ} \mathrm{C}$ for 24 hours & 4.96 & {$[81]$} \\
\hline Chlorococcum infusionum & $\begin{array}{l}\text { Chemical } \\
(0.75 \% \mathrm{NaOH}) \text { with hydrothermal } \\
\text { pretreatment }\left(120^{\circ} \mathrm{C}\right)\end{array}$ & $200 \mathrm{rpm}$ and $30^{\circ} \mathrm{C}$ for 72 hours & 26.13 & {$[83]$} \\
\hline Chlorella sp. & $\begin{array}{l}\text { Chemical } \\
(2 \% \mathrm{NaOH}) \text { with hydrothermal } \\
\text { pretreatment }\left(120^{\circ} \mathrm{C}\right)\end{array}$ & $100 \mathrm{rpm}$ and $30^{\circ} \mathrm{C}$ for 96 hours & 1.01 & {$[84]$} \\
\hline
\end{tabular}

biobutanol production. Generally, ABE fermentation is performed using Clostridium sp. bacteria as the biocatalyst that will convert carbohydrates or starches from microalgal biomass into acetone, butanol, and ethanol under anaerobic conditions in a molar ratio of 3:6:1 as per (Eq. (3)).

$$
\begin{aligned}
\left(\mathrm{C}_{6} \mathrm{H}_{10} \mathrm{O}_{5}\right)_{10}+9 \mathrm{H}_{2} \mathrm{O} \rightarrow & 3 \mathrm{C}_{3} \mathrm{H}_{6} \mathrm{O}+6 \mathrm{C}_{4} \mathrm{H}_{10} \mathrm{O}+\mathrm{C}_{2} \mathrm{C}_{6} \mathrm{O}+24 \mathrm{CO}_{2} \\
& +16 \mathrm{H}_{2}+\text { Biomass }
\end{aligned}
$$

Starch Acetone Butanol Ethanol

Early research on biobutanol production from various types of feedstock, such as palm kernel cakes, empty EFB, rice straw, and macroalgae have been noted [88-92]. To the best of our knowledge, there is little information on the production of biobutanol from microalgal biomass. A previous study on $\mathrm{ABE}$ fermentation of different types of microalgal biomass, such as Arthrospira platensis, Nannochloropsis sp., Dunaliella tertiolecta, Galdieria partita, C. vulgaris, Cosmarium sp., and Nostoc sp., has indicated that the production of biobutanol significantly depends on the carbohydrate composition and type of microalgal strain [93]. Other studies on the fermentation of whole microalgal cells cultivated in wastewater showed great potential for biobutanol production with butanol and ABE concentrations of 3.74 and $5.23 \mathrm{~g} \mathrm{l}^{-1}$, respectively. These results were acquired from $3.5 \mathrm{~g}$ of microalgal biomass [94]. Later studies revealed that ABE fermentation of acidhydrolyzed C. vulgaris biomass using Clostridium acetobutylicum strain produced approximately 3.37 and $5.14 \mathrm{~g} \mathrm{l}^{-1}$ of butanol and ABE, respectively [95]. A similar observation was also reported by Wang et al. [96] who demonstrated that the initial biomass concentration significantly affected $\mathrm{ABE}$ fermentation and solvent production. According to the study on ABE fermentation using different initial biomass concentrations of 20,40,60, and $80 \mathrm{~g} \mathrm{l}^{-1}$, further increased initial biomass concentrations would significantly improve biobutanol production. The maximum butanol production from the ABE fermentation of mutant $C$. vulgaris was achieved when the fermentation was carried out using $80 \mathrm{~g} \mathrm{l}^{-1}$ of biomass. Kassim et al. [97] also investigated the potential of biobutanol production from alkali-pretreated marine microalgae T. suecica. It was found that a total of $0.14 \mathrm{~g} \mathrm{l}^{-1}$ of butanol was produced from ABE fermentation using Clostridium saccharoperbutylacetonicum N1-4. Low biobutanol production from this study might be due to the low biomass concentration used during fermentation. Low biobutanol production from this study could be attributed to the fermentation using a low biomass concentration; however, it is insufficient to trigger the metabolic solventogenesis pathway for $\mathrm{ABE}$ production. This resulted in a low solvent concentration as nearly all the sugar in the hydrolysate had been converted into an organic acid during the fermentation process. Generally, ABE fermentation involves two major fermentation stages: acetogenesis and solventogenesis. Acetogenesis is a biological process that converts the available carbon source into organic acids such as butyrate and acetate, while solventogenesis is a biochemical production of solvents such as acetone and butanol. According to these studies, it indicated that suitable amount of initial biomass plays an important role to undergo the solventogenesis process during the fermentation process. On the other hand, it was also reported that biobutanol production from microalgae can be affected by the pretreatment process. A pretreatment process affecting the ABE fermentation process was indicated by a previous study [98]. This study compared production of biobutanol from two types of microalgae biomass samples extracted using different solvents namely ionic liquid extracted algae (ILEA) as well as hexane extracted algae (HEA) and resulted that the highest butanol production was achieved from the fermentation of HEA sample with a butanol concentration of $8.05 \mathrm{~g} \mathrm{l}^{-1}$. The overall ABE productivity gave $0.35 \mathrm{~g} \mathrm{l}^{-1}$ hours $^{-1}$ for ILEA and $0.32 \mathrm{~g} \mathrm{l}^{-1}$ hours $^{-1}$ for HEA.

\subsubsection{Biohydrogen}

The production of biohydrogen from microalgal carbohydrates is one of the renewable processes to produce alternative bioenergy from microalgae biomass. Biohydrogen is a very favorable 


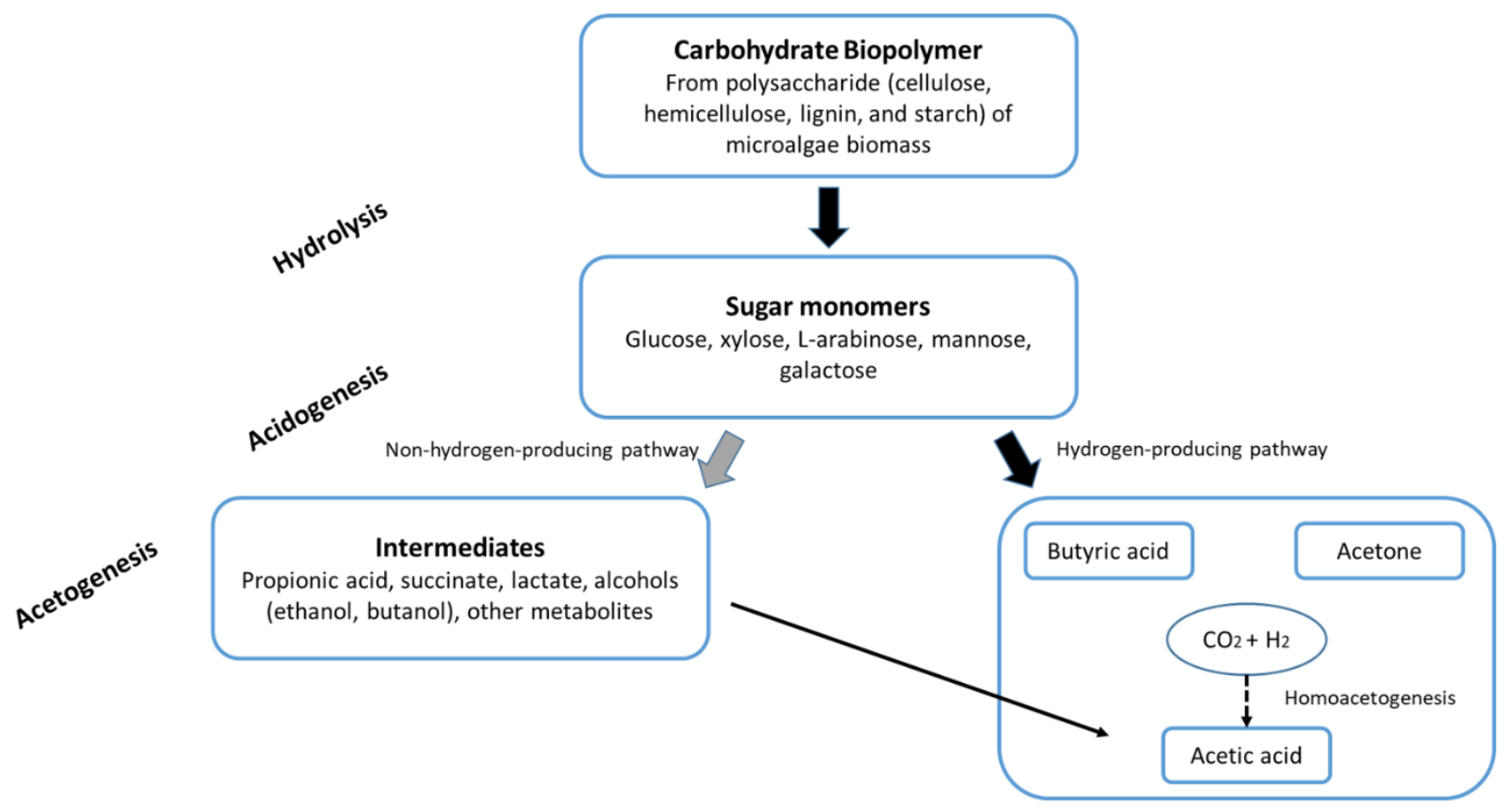

Figure 6. Dark fermentation pathway for biohydrogen production (adapted from Monlau et al. [107]).

renewable fuel for its high-energy content (i.e., $118.7 \mathrm{~kJ} \mathrm{~g}^{-1}$ ) as it yields an output four times higher than bioethanol and methane. Generally, biohydrogen is a product from the fermentation of organic carbon from various types of microorganisms, including microalgae, bacteria, and cyanobacteria. These microorganisms produce hydrogen by releasing electrons during its metabolic reaction as follows:

$$
2 \mathrm{e}+2 \mathrm{H}_{2} \mathrm{O} \rightarrow \mathrm{H}_{2}+2 \mathrm{H}_{2} \mathrm{O}
$$

The generation of biohydrogen can be carried out biologically through biophotolysis of $\mathrm{H}_{2} \mathrm{O}$, photoreduction, and fermentation [99]. Biohydrogen from microalgal carbohydrates is typically obtained from either dark or an autofermentation process. In dark fermentation, the process is performed by hydrolyzing complex organic polymers via hydrogen-producing bacteria, such as Clostridium butylicium without the presence of $\mathrm{H}_{2} \mathrm{O}, \mathrm{O}_{2}$, and sunlight. At the end of the process, other high value-added chemicals, such as butyric acid, lactic acid, and acetic acid are produced. On the other hand, photofermentation is a conversion of organic polymers into biohydrogen and $\mathrm{CO}_{2}$. This is performed with the presence of sunlight as an energy source. Theoretically, 4 mol of hydrogen could be produced from each mol of glucose, which corresponds to $33 \%$ energy yield of the reaction.

$$
\mathrm{C}_{6} \mathrm{H}_{12} \mathrm{O}_{6}+2 \mathrm{H}_{2} \mathrm{O} \rightarrow 2 \mathrm{CH}_{3} \mathrm{COO}+2 \mathrm{H}+2 \mathrm{CO}_{2}+4 \mathrm{H}_{2}
$$

Various microalgal species including Chlorella sp., Scenedesmus sp., Nannochloropsis sp., and S. platensis as biohydrogen feedstock have been extensively considered [100-102]. Microalgal carbohydrate content and its pretreatment process are imperative in order to ensure the efficiency of biohydrogen production.

Batch fermentation of lipid-extracted Scenedesmus sp. has been generated from different pretreatment processes including acid, base, chloroform, and a heat produced maximum biohydrogen concentration of $36 \mathrm{~g} \mathrm{VS}^{-1}$. This occurs when the fermentation was conducted using heat-treated microalgal biomass [103]. Studies have also indicated that utilizing a lipid-extracted sample could give dual benefits to microalgal biorefineries, including renewable energy production and sustainable biodiesel production. Dark fermentation has been used for biohydrogen production. Monosaccharides (e.g., glucose and mannose) and polymers, such as cellulose found in microalgal cells, can be used as biohydrogen feedstock. The production of biohydrogen using dark fermentation is explained via two pathways. One pathway produces acetate and the other produces butyrate. Both pathways are shown in Figure 6. Dark fermentation of $C$. reinhardtii hydrolysate from heat treatment and enzyme hydrolysis using Thermotoga neapolitana had been reportedly shown to be the highest biohydrogen production at $2.5 \mathrm{~mol} \mathrm{H}_{2}$ /sugar from the enzymatic hydrolysis sample [104]. This suggested that easier digestibility and suitable steps to break the microalgal cell walls are vital to obtain high biohydrogen. Similarly, for the fermentation of Chlorella sorokiniana that was pretreated using the $\mathrm{HCl}$ heat approach, autoclaving, and sonication, the most suitable pretreatment was the $\mathrm{HCl}$-heat method. The fermentation process was able to obtain the maximum biohydrogen amount of 685 $\mathrm{dm}^{-3} \mathrm{~kg}^{-1}$ [105]. Biohydrogen production via photofermentation has also been reported previously even though its production was slightly lower than dark fermentation. Hwang et al. [106] concluded that the photofermentation of Chlorella sp. YSL01 and YSL16 was able to produce biohydrogen under cultivation when exposed to continuous illumination. The study mentioned that $\mathrm{O}_{2}$ concentration played a significant role in affecting the biohydrogen production via this approach. The information generated could give new insights into the development of biomimetic photovoltaic cells using microalgae as suggested. Table 5 summarizes the types 
Table 5: The types of pretreatments, fermentation conditions, and biohydrogen yield based on different microalgae strains.

\begin{tabular}{|c|c|c|c|c|}
\hline Microalgae strain & Pretreatment & Condition (fermentation) & Hydrogen yield & Reference \\
\hline Chlorella vulgaris & $1.6 \%$ of $\mathrm{HCl}$, sonicate for 35 minutes & $\begin{array}{l}\text { Batch, } 35^{\circ} \mathrm{C} \text {, heat-treated } \\
\text { anaerobic sludge }\end{array}$ & $36.5 \mathrm{ml} \mathrm{H}_{2} \mathrm{~g}^{-1} \mathrm{VS}$ & [108] \\
\hline Scenedesmus obliquus & Sonicate for 15 minutes at $45^{\circ} \mathrm{C}$ & $\begin{array}{l}\text { Batch, } 55^{\circ} \mathrm{C} \text {, heat-treated } \\
\text { anaerobic sludge }\end{array}$ & $56 \mathrm{ml} \mathrm{H}_{2} \mathrm{~g}^{-1}$ biomass & [109] \\
\hline Chlorella pyrenoidosa & $1 \% \mathrm{H}_{2} \mathrm{SO}_{4}, 135^{\circ} \mathrm{C}$ for 15 minutes & $\begin{array}{l}\text { Semicontinuous, } 35^{\circ} \mathrm{C} \text {, heat- } \\
\text { treated anaerobic sludge }\end{array}$ & $56.1 \mathrm{~mL} \mathrm{H}_{2} \mathrm{~g}^{-1} \mathrm{VS}$ & {$[110]$} \\
\hline Chlamydomonas reinhardtii & Sulfur-starvation & - & 100 to $300 \mathrm{ml} \mathrm{l}^{-1}$ & {$[112]$} \\
\hline Anabaena variabilis & Nitrogen-starvation & Continuous photoautotrophic & $4.1 \mathrm{ml} \mathrm{H}_{2} \mathrm{~g}^{-1}$ biomass & [113] \\
\hline Nannochloropsis oceanica & - & $\begin{array}{l}\text { Batch, } 35^{\circ} \mathrm{C} \text {; Anaerobic sludge, } \\
\text { pH } 6.0\end{array}$ & $2 \mathrm{ml} \mathrm{H}_{2} \mathrm{~g}^{-1} \mathrm{VS}$ & [114] \\
\hline
\end{tabular}

of pretreatment, fermentation conditions, and biohydrogen yields based on different microalgae strains.

\section{CHALLENGES AND FUTURE PROSPECTS}

Even though there are many studies on the potential of the microalgae biomass as a feedstock for various products, several challenges exist and limitations arise in the aspect of upstream to downstream stages including cultivations for biomass production and subsequent final product processing.

Manipulation of microalgae cultivation at the upstream stage is important when solving the conflict between biomass production and carbohydrate accumulation. Minimal effort is needed when selecting the most suitable condition to obtain maximum biomass and carbohydrate production. Notably, the growth and carbohydrate accumulation of microalgae are species-dependent and require approximately two weeks to obtain maximum biomass concentration. A comprehensive investigation on cultivation for specific indigenous microalgae regarding biomass production and carbohydrate accumulation is important to ensure the feasibility of biofuel and fine chemical production. This is especially true when using a cheap medium within a short period of time. Cultivation using wastewater and $\mathrm{CO}_{2}$ from flue gas has been suggested as a promising approach to overcome cultivation issues. Further exploration on microalgae cultivation either mixotrophic or heterotrophic methods using cheap carbon sources could indirectly secure energy and food supply in the local industry. For example, by-products from agriculture or chemical industries for indigenous strain need to be well established,

Other common challenges in the production of biofuel and chemicals from microalgae carbohydrate are pretreatment and hydrolysis for sugar extraction prior to the fermentation process. Recently, many pretreatment and hydrolysis technologies have been introduced to extract sugar from microalgal biomass. However, most of the technology involves a two-step process. Utilized and substantial amounts of chemicals such as alkaline and acids as a catalyst during the process are required. The innovation on single pretreatment and hydrolysis steps should be explored to improve the process that could significantly reduce reaction time and energy consumption. This will eventually reduce production costs. Technologies such as supercritical liquid extractions, supercritical $\mathrm{CO}_{2}$ extractions, or ionic liquid on different microalgal species are believed to be explored to establish a database for biofuel and chemical production from microalgal carbohydrates. Recent studies have indicated a low sugar production at high initial feedstock results in low hydrolysis efficiency. Thus, improvement of hydrolysis performance is needed in order to obtain a high sugar level for the fermentation process.

Generally, the production of biofuels and fine chemicals from microalgae carbohydrates involves bioconversion using microorganisms as biocatalysts. At this stage, several challenges and limitations associated with these processes have been identified. For instance, low final product production may result due to the presence of bacterial inhibitors which limit growth. Advance fermentation technology known to reduce inhibitors generated during the fermentation process is needed to improve fermentation performance. A single bioreactor with an extraction apparatus would be beneficial in reducing the reaction process and fermentation performance.

\section{CONCLUSIONS}

Based on the discussion above, it is clear that microalgal carbohydrates have great potential in the chemical platform for the production of various types of chemicals. High carbohydrate content in microalgal biomass could be promising for biohydrogen, liquid fuels, organic acids, and solvent production. But there are several limitations to the development of the economically feasible microalgal biorefinery. Increasing the carbohydrate yield in the microalgae through various strategies such as cultivating the microalgae using manipulation of the cultivation system under optimum abiotic conditions is essential. Further innovation to push the establishment of affordable and environmentally friendly pretreatment methods is particularly needed to make carbohydratebased products preferable. Therefore, the development of a systematic approach via the integration of biotechnology and chemical conversion approach is required to ensure the feasibility of microalgal carbohydrate biorefinery. 


\section{ACKNOWLEDGEMENT}

The authors would like to acknowledge the School of Industrial Technology, Universiti Sains Malaysia (USM), for their consistent support to write this review paper. The project and manuscript preparation were financially supported by the RUI Grant 1001/ PTEKIND/8011043 and USM Fellowship RU(1001/CIPS/ AUPE001) from Universiti Sains Malaysia.

\section{AUTHOR CONTRIBUTIONS}

All authors made substantial contributions to conception and design, acquisition of data, or analysis and interpretation of data; took part in drafting the article or revising it critically for important intellectual content; agreed to submit to the current journal; gave final approval of the version to be published; and agree to be accountable for all aspects of the work. All the authors are eligible to be an author as per the international committee of medical journal editors (ICMJE) requirements/guidelines.

\section{FUNDING}

The project and manuscript preparation were financially supported by the RUI Grant 1001/ PTEKIND/8011043 and USM Fellowship RU(1001/CIPS/ AUPE001) from Universiti Sains Malaysia.

\section{ETHICAL APPROVALS}

This study does not involve experiments on animals or human subjects.

\section{CONFLITS OF INTEREST}

The authors declare that there are no conflicts of interest.

\section{REFERENCES}

1. Balan V. Current challenges in commercially producing biofuels from lignocellulosic biomass. ISRN Biotechnol 2014;2014:463074-105.

2. Harun R, Danquah MK. Influence of acid pre-treatment on microalgal biomass for bioethanol production. Process Biochem 2011;46:304-9.

3. Debowsk M, Zielinski M, Kazimierowicz J, Kujawska N, Talbierz S. Microalgae cultivation technologies as an opportunity for bioenergetic system development-advantages and limitations. Sustainability 2020;12(23):9980-10017.

4. Paes CR, Faria GR, Tinoco NA, Castro DJ, Barbarino E, Lourenço SO. Growth, nutrient uptake and chemical composition of Chlorella sp. and Nannochloropsis oculata under nitrogen starvation. Lat Am J Aquat Res 2016;44(2):275-92.

5. Uma BH, Kim YS. Review: a chance for Korea to advance algalbiodiesel technology. J Ind Eng Chem 2009;15(1):1-7.

6. Rout J, Sharma B, Swain S, Mishra S. Algae in nutrition and colouration of ornamental fish: a review. Renew Sust Energ 2013;14(2):578-97.

7. Costard GS, Machado RR, Barbarino E, Martino RC, Lourenccedil SO. Chemical composition of five marine microalgae that occur on the Brazilian coast. Int J Fish Aquac 2012;4(9):191-201.

8. Tibbetts SM, Milley JE, Lall SP. Chemical composition and nutritional properties of freshwater and marine microalgal biomass cultured in photobioreactors. J Appl Phycol 2014;27(3):1109-19.

9. Dineshkumar R, Narendran R, Jayasingam P, Sampathkumar P. Cultivation and chemical composition of microalgae Chlorella vulgaris and its antibacterial activity against human pathogens. J Aquacu Mar Biol 2017;5:00119.

10. Srinivasan R, Mageswari A, Subramanian P, Suganthi C, Chaitanyakumar A, Aswini V, et al. Bicarbonate supplementation enhances growth and biochemical composition of Dunaliella salina
V-101 by reducing oxidative stress induced during macronutrient deficit conditions. Sci Rep 2018;8:6972.

11. German-Báez LJ, Valdez-Flores MA, Fe'lix-Medina JV, NorzagarayValenzuela CD, Santos-Ballardo DU, Reyes-Moreno C, et al. Chemical composition and physicochemical properties of Phaeodactylum tricornutum microalgal residual biomass. Food Sci Technol Int 2017;23(8):681-9.

12. Chew KW, Yap JY, Show PL, Suan NH, Juan JC, Ling TC, et al. Microalgae biorefinery: high value products perspectives. Bioresour Technol 2017;229:53-62.

13. Visca A, Di Caprio F, Spinelli R, Altimari P, Cicci A, Iaquaniello G, et al. Microalgae cultivation for lipids and carbohydrates production. Chem Eng Trans 2017;57:127-32.

14. Cheng D, Li D, Yuan $\mathrm{Y}$, Zhou L, Li X, Wu T, et al. Improving carbohydrate and starch accumulation in Chlorella sp. AE10 by a novel two-stage process with cell dilution. Biotechnol Biofuels 2017;10(1):75-89.

15. Meyer BL. Of fruits and fishes: a space farm and recycling concept. AIAA Space Conference and Exposition, Pasadena, California Conference Paper, 2015, 1-30.

16. Möllers KB, Cannella D, Jørgensen H, Frigaard NU. Cyanobacterial biomass as carbohydrate and nutrient feedstock for bioethanol production by yeast fermentation. Biotechnol Biofuels 2014;7(1):64.

17. Al Abdallah Q, Nixon BT, Fortwendel JR. The enzymatic conversion of major algal and cyanobacterial carbohydrates to bioethanol. Front Energ Res 2016;4:36.

18. Kuchitsu K, Tsuzuki M, Miyachi S. Changes of starch localization within the chloroplast induced by changes in $\mathrm{CO}_{2}$ concentration during growth of Chlamydomonas reinhardtii: independent regulation of pyrenoid starch and stroma starch. Plant Cell Physiol 1988;29(8):1269-78.

19. Cho YG, Kang KK. Functional analysis of starch metabolism in plants. Plants 2020;9(9):1152.

20. Queiroz MI, Vieira JG, Maroneze MM. Morphophysiological, structural, and metabolic aspects of microalgae. Handbook of microalgae-based processes and products. Elsevier, The Netherlands, pp 25-48, 2020.

21. Panahi Y, Khosroushahi AY, Sahebkar A, Heidari HR. Impact of cultivation condition and media content on Chlorella vulgaris composition. Adv Pharm Bull 2019;9(2):182-94.

22. Kassim MA, Rashid MA, Halim R. Towards biorefinery production of microalgal biofuels and bioproducts: Production of acetic acid from the fermentation of Chlorella $\mathrm{sp}$. and Tetraselmis suecica hydrolysates. Green Sustain Chem 2017;7:152-71.

23. PedruziMatheus GOL, Amorim ML, Santos RR, Martins MA, Vaz MGMV. Biomass accumulation-influencing factors in microalgae farms. Braz J Agri Environ Eng 2020;24(2):134-9.

24. Juneja A, Ceballos RM, Murthy GS. Effects of environmental factors and nutrient availability on the biochemical composition of algae for biofuels production: a review. Energies 2013;6:4607-38.

25. Krichen E, Rapaport A, Floc'h EL, Fouilland E. Demonstration of facilitation between microalgae to face environmental stress. Sci Rep 2019;9:16076.

26. Tang YZ, Gin KYH, Aziz MA. The relationship between $\mathrm{pH}$ and heavy metal ion sorption by algal biomass. Adsorp Sci Technol 2003;21(6):525-37.

27. Vadlamani A, Viamajala S, Pendyala B, Varanasi S. Cultivation of microalgae at extreme alkaline $\mathrm{pH}$ conditions: a novel approach for biofuel production. ACS Sustain Chem Eng 2017;5(8):7284-94

28. Suali E, Sarbatly R, Anisuzzaman S, Lahin FA, Asidin MA, Jusnukin T. Effect of membrane on carbonation and carbon dioxide uptake of Chlorella sp. MATEC Web of Conferences, Kota Kinabalu, Sabah Malaysia, vol 111, pp 1-7, 2017.

29. Liu W, Au DWT, Anderson DM, Lam PKS, Wu RSS. Effects of nutrients, salinity, $\mathrm{pH}$ and light:dark cycle on the production of reactive oxygen species in the alga Chattonella marina. J Exp Mar Biol Ecol 2007;346:76-86. 
30. Zhang Q, Wang T, Hong Y. Investigation of initial $\mathrm{pH}$ effects on growth of an oleaginous microalgae Chlorella sp. HQ for lipid production and nutrient uptake. Water Sci Technol 2014;70(4):712-9.

31. Uggetti E, Sialve B, Hamelin J, Bonnafous A, Steyer JP. $\mathrm{CO}_{2}$ addition to increase biomass production and control microalgae species in high rate algal ponds treating wastewater. $\mathrm{J} \mathrm{CO}_{2}$ Util 2018;28:292-8.

32. Qiu R, Gao S, Lopez PA, Ogden KL. Effects of pH on cell growth, lipid production and $\mathrm{CO}_{2}$ addition of microalgae Chlorella sorokiniana. Algal Res 2017;28:192-9.

33. Peng X, Meng F, Wang Y, YiX, Cui H. Effect of pH, temperature, and $\mathrm{CO}_{2}$ concentration on growth and lipid accumulation of Nannochloropsis sp. MASCC 11. J Ocean Univ China 2020;19(5):1183-92.

34. Patil L, Kaliwal B. Effect of $\mathrm{CO}_{2}$ concentration on growth and biochemical composition of newly isolated indigenous microalga Scenedesmus bajacalifornicus BBKLP-07. Appl Bochem Biotechnol 2017;182(1):335-48.

35. Zhu B, Chen G, Cao X, Wei D. Molecular characterization of $\mathrm{CO}_{2}$ sequestration and assimilation in microalgae and its biotechnological applications. Bioresour Technol 2017;244:1207-15.

36. Cheng D, Li D, Yuan Y, Zhou L, Li X, Wu T, et al. Improving carbohydrate and starch accumulation in Chlorella sp. AE10 by a novel two-stage process with cell dilution. Biotechnol Biofuels 2017;10(1):1-4.

37. Li D, Wang L, Zhao Q, Wei W, Sun Y. Improving high carbon dioxide tolerance and carbon dioxide fixation capability of Chlorella sp. by adaptive laboratory evolution. Bioresour Technol 2015;185:269-75.

38. Kassim MA, Tan KM. Carbon dioxide $\left(\mathrm{CO}_{2}\right)$ biofixation by microalgae and its potential for biorefinery and biofuel production. Sci Total Environ 2017;584-585:1121-9.

39. Mutah M, Ayoko GA, Ward A, Rösch C, Brown RJ, Rainey TJ. Factors affecting microalgae production for biofuels and the potentials of chemometric methods in assessing and optimizing productivity. Cells 2019;8(8):851-76.

40. Yahya L, Harun R, Abdullah LC. Screening of native microalgae species for carbon fixation at the vicinity of Malaysian coal-fired power plant. Sci Rep 2020;10(1):22355.

41. Maynardo JJ, Doshi V, Rajanren R, Rajasekaran R. The optimization of light intensity and drying temperature on lipid content of microalgae Nannochloropsis oculata. J Eng Sci Technol 2015;1:112-21.

42. Ras M, Steyer JP, Bernard O. Temperature effect on microalgae: a crucial factor for outdoor production. Rev Environ Sci Bio/Technol 2013;12(2):153-64.

43. Nadzir SM, Yusof N, Nordin N, Abdullah H, Kamari A. Combination effect of temperature and light intensity on lipid productivity of Tetradesmus obliquus. Journal of Physics: Conference Series, IOP Publishing, Bristol, UK, pp 10971-10, 2018.

44. Khoyi ZA, Seyfabadi J, Ramezanpour Z. Effects of light intensity and photoperiod on the growth rate, chlorophyll a and $\beta$-carotene of freshwater green micro alga Chlorella vulgaris. Comp Biochem Physiol Part A 2009;153(2):S209-18.

45. Liu J, Lu Y, Hua W, Last RL. A new light on photosystem II maintenance in oxygenic photosynthesis. Front Plant Sci 2019;10:975-85.

46. Liu X, Ying K, Chen G, Tao Y, Cai Z, Wang J. Influence of light intensity on microalgal growth, nutrients removal and capture of carbon in the wastewater under intermittent supply of $\mathrm{CO}_{2}$. J Chem Technol Biotechnol 2018;93(12):3582-9.

47. Carvalho AP, Monteiro CM, Malcata FX. Simultaneous effect of irradiance and temperature on biochemical composition of the microalga Pavlova lutheri. J Appl Phycol 2009;21:543-52.

48. He Q, Yang H, Wu L, Hu C. Effect of light intensity on physiological changes, carbon allocation and neutral lipid accumulation in oleaginous microalgae. Bioresour Technol 2015;191:219-28.

49. Yee-keung W, Kin-chung $H$. Optimization for cultivation of microalgae Chlorella vulgaris and lipid production in photobioreactor. Open University of Hong Kong, Kowloon, Hong Kong, pp 1-6, 2016.
50. Kucharska K, Rybarczyk P, Hołowacz I, Łukajtis R, Glinka M, Kamiński M. Pretreatment of lignocellulosic materials as substrates for fermentation processes. Molecules 2018;23(11):2937-69.

51. Günerken E, D'Hondt E, Eppink MHM, Garcia-Gonzalez L, Elst K, Wijffels RH. Cell disruption for microalgae biorefineries. Biotechnol Adv 2015;33:243-60.

52. Halim R, Harun R, Danquah MK, Webley PA. Microalgal cell disruption for biofuel development. Appl Energy 2012;91:116-21.

53. de Farias Silva CE, Meneghello D, Abud AKDS, Bertucco A. Pretreatment of microalgal biomass to improve the enzymatic hydrolysis of carbohydrates by ultrasonication: yield vs energy consumption. J King Saud Univ Sci 2020;32(1):606-13.

54. Kim KH, Choi IS, Kim HM, Wi SG, Base HJ. Bioethanol production from the nutrient stress-induced microalga Chlorella vulgaris by enzymatic hydrolysis and immobilized yeast fermentation. Bioresour Technol 2014;153:47-54.

55. Eldalatony MM, Kabra AN, Hwang JH, Govindwar SP, Kim KH, Kim $\mathrm{H}$, et al. Pretreatment of microalgal biomass for enhanced recovery/ extraction of reducing sugars and proteins. Bioprocess Biosyst Eng 2016;39(1):95-103.

56. Kim KH, Choi IS, Kim HM, Wi SG, Base HJ. Bioethanol production from the nutrient stress-induced microalga Chlorella vulgaris by enzymatic hydrolysis and immobilized yeast fermentation. Bioresour Technol 2014;153:47-54.

57. Alavijeh RS, Karimi K, Wijffels RH, Berg CVD. Combined bead milling and enzymatic hydrolysis for efficient fractionation of lipids, proteins, and carbohydrates of Chlorella vulgaris microalgae. Bioresour Technol 2020;309(7):123322.

58. Rincón-Pérez J, Flores ER, Morales M, Mondragon FA, Celis LB. Improving the biodegradability of Scenedesmus obtusiusculus by thermochemical pretreatment to produce hydrogen and methane. BioEnergy Res 2019;13:1-0.

59. Mendez L, Mahdy A, Ballesteros M, Fernandez CG. Methane production of thermally pretreated Chlorella vulgaris and Scenedesmus sp. biomass at increasing biomass loads. Appl Energy 2014;129:238-42.

60. Laurens L, Nagle N, Davis R, Sweeney N, Wychen SV, Lowell A, et al. Acid-catalyzed algal biomass pretreatment for integrated lipid and carbohydrate-based biofuels production. Green Chem 2015; 17(2):1145-58.

61. Lee OK, Kim AL, Seong DH, Lee CG, Jung YT, Lee JW, et al. Chemoenzymatic saccharification and bioethanol fermentation of lipidextracted residual biomass of the microalga, Dunaliella tertiolecta. Bioresour Technol 2013;132:197-201.

62. Mahdy A, Mendez L, Ballesteros M, Fernandez CG. Autohydrolysis and alkaline pretreatment effect on Chlorella vulgaris and Scenedesmus sp. methane production. Energy 2014;78:48-52.

63. Kassim MA, Bhattacharya S. Dilute alkaline pretreatment for reducing sugar production from Tetraselmis suecica and Chlorella sp. biomass. Process Biochem 2016;51:1757-66.

64. Mahdy A, Mendez L, Ballesteros M, Fernandez CG. Enhanced methane production of Chlorella vulgaris and Chlamydomonas reinhardtii by hydrolytic enzymes addition. Energy Convers Manag 2014;85:551-7.

65. Fu CC, Hung TC, Chen JY, Su CH, Wu WT. Hydrolysis of microalgae cell walls for production of reducing sugar and lipid extraction. Bioresour Technol 2010;101(22):8750-4.

66. Vingiani GM, De Luca P, Ianora A, Dobson ADW, Lauritano C. Microalgal enzymes with biotechnological applications. Mar Drugs 2019;17(8):459-79.

67. Vasic K, Knez Z, Leitgeb M. Bioethanol production by enzymatic hydrolysis from different lignocellulosic sources. Molecules 2021;26(3):753.

68. Robak K, Balcerek M. Review of second generation bioethanol production from residual biomass. Food Technol Biotechnol 2018;56(2):174-87. 
69. Mahdy A, Mendez L, Tomás-Pejó E, del Mar Morales M, Ballesteros M, González-Fernández, C. Influence of enzymatic hydrolysis on the biochemical methane potential of Chlorella vulgaris and Scenedesmus sp. J Chem Technol Biotechnol 2016;91(5):1299-305.

70. Ngamsirisomsakul M, Reungsang A, Liao Q, Kongkeitkajorn MB. Enhanced bio-ethanol production from Chlorella sp. biomass by hydrothermal pretreatment and enzymatic hydrolysis. Renew Energy 2019;141:482-92.

71. Saleh NIM, Ghani WAWAK, Harun MR, Kamal SMM. Optimization of enzymatic hydrolysis for the production of antioxidative peptide from Nannochloropsis gaditana using response surface methodology. Adapt Challenges 2019;27(S1):41-55.

72. Choi SP, Nguyen MT, Sim SJ. Enzymatic pretreatment of Chlamydomonas reinhardtii biomass for ethanol production. Bioresour Technol 2010;101:5330-6.

73. Agbor VB, Cicek N, Sparling R, Berlin A, Levin DB. Biomass pretreatment: fundamentals toward application. Biotechnol Adv 2011;29:675-85.

74. Ho SH, Huang SW, Chen CY, Hasunuma T, Kondo A, Chang JS. Bioethanol production using carbohydrate-rich microalgae biomass as feedstock. Bioresour Technol 2013;135:191-8.

75. El-Dalatony MM, Kurade MB, Abou-Shanab RAI, Kim H, Salam E, Jeon B. Long-term production of bioethanol in repeated-batch fermentation of microalgal biomass using immobilized Saccharomyces cerevisiae. Bioresour Technol 2016;219:98-105.

76. Harun R, Danquah MK, Forde Gareth MF. Microalgal biomass as a fermentation feedstock for bioethanol production. J Chem Technol Biotechnol 2009;85:199-203.

77. Danquah M, Liu B, Harun R. Analysis of process configurations for bioethanol production from microalgal biomass. In: Shaukat $\mathrm{S}$ (ed.). Progress in biomass and bioenergy production, IntechOpen, London, UK, pp 395-408, 2011.

78. Subhedar PB, Gogate PR. Intensification of enzymatic hydrolysis of lignocellulose using ultrasound for efficient bioethanol production: a review. Ind Eng Chem Res 2013;52(34):11816-28.

79. Aikawa S, Joseph A, Yamada R, Izumi Y, Yamagishi T, Matsuda F, et al. Direct conversion of Spirulina to ethanol without pretreatment or enzymatic hydrolysis processes. Energy Environ Sci 2013;6(6):18449.

80. Phwan CK, Chew KW, Sebayang AH, Ong HC, Ling TC, Malek MA, et al. Effects of acids pre-treatment on the microbial fermentation process for bioethanol production from microalgae. Biotechnol Biofuels 2019;12(1):191-9.

81. Shokrkar H, Ebrahimi S, Zamani M. Bioethanol production from acidic and enzymatic hydrolysates of mixed microalgae culture. Fuel 2017;200:380-6.

82. Khan MI, Lee MG, Shin JH, Kim JD. Pretreatment optimization of the biomass of Microcystis aeruginosa for efficient bioethanol production. Amb Express 2017;7(1):19-28.

83. Harun R, Jason W, Cherrington T, Danquah MK. Exploring alkaline pre-treatment of microalgal biomass for bioethanol production. Appl Energy 2011;88(10):3464-7.

84. Kassim MA, Tan KM, Serri NA. Enzymatic hydrolysis of dilute alkaline pretreated Chlorella sp. biomass for biosugar production and fed-batch bioethanol fermentation. Asia-Pac J Sci Technol 2019;24(1):1-6

85. Lee SY, Kim HU, Chae TU, Cho JS, Kim JW, Shin JH, et al. A comprehensive metabolic map for production of bio-based chemicals. Nat Catal 2019;2:18-33.

86. Yusoff M, Zulkifli N, Masum B, Masjuki H. Feasibility of bioethanol and biobutanol as transportation fuel in spark-ignition engine: a review. RSC Adv 2015;5(121):100184-211.

87. García V, Päkkilä J, Ojamo H, Muurinen E, Keiski RL. Challenges in biobutanol production: how to improve the efficiency? Renew Sustain Energy Rev 2011;15(2):964-80.
88. Dubey KK, Dhingra AK, Rana S. Optimisation of process parameters for enhanced biobutanol production from Sargassum wightii hydrolysate. Int J Energy Technol Policy 2015;11(3):303-11.

89. Ibrahim MF, Abd-Aziz S, Razak MNA, Phang LY, Hassan MA. Oil palm empty fruit bunch as alternative substrate for acetone-butanolethanol production by Clostridium butyricum EB6. Appl Biochem Biotechnol 2012;166(7):1615-25.

90. Ranjan A, Mayank R, Moholkar VS. Process optimization for butanol production from developed rice straw hydrolysate using Clostridium acetobutylicum MTCC 481 strain. Biomass Convers Biorefin 2013;3(2):143-55.

91. Shukor H, Al-Shorgani NKN, Abdeshahian P, Hamid AA, Anuar N, Rahman NA, et al. Biobutanol production from palm kernel cake (PKC) using Clostridium saccharoperbutylacetonicum N1-4 in batch culture fermentation. BioResources 2014;9(3):5325-38.

92. van der Wal H, Sperber BL, Houweling-Tan B, Bakker RR, Brandenburg W, López-Contreras AM. Production of acetone, butanol, and ethanol from biomass of the green seaweed Ulva lactuca. Bioresour Technol 2013;128:431-7.

93. Efremenko EN, Nikolskaya AB, Lyagin IV, Senko OV, Makhlis TA, Stepanov NA, et al. Production of biofuels from pretreated microalgae biomass by anaerobic fermentation with immobilized Clostridium acetobutylicum cells. Bioresour Technol 2012;114:342-8.

94. Castro YA, Ellis JT, Miller CD, Sims RC. Optimization of wastewater microalgae saccharification using dilute acid hydrolysis for acetone, butanol, and ethanol fermentation. Appl Energy 2015;140:14-9.

95. Wang Y, Guo WQ, Lo YC, Chang JS, Ren NQ. Characterization and kinetics of bio-butanol production with Clostridium acetobutylicum ATCC824 using mixed sugar medium simulating microalgae-based carbohydrates. Biochem Eng J 2014;91:220-30.

96. Wang Y, Guo WQ, Chang JS, Ren NQ. Butanol production using carbohydrate-enriched Chlorella vulgaris as feedstock. Adv Mater Res 2014;830:12-25.

97. Kassim MA, Potumarthi R, Tanksale A, Srivatsa S, Bhattacharya S. Enzymatic saccharification of dilute alkaline pre-treated microalgal (Tetraselmis suecica) biomass for biobutanol production. Int J Food Agric Vet Sci 2014;8:967-72.

98. Gao K, Orr V, Rehmann L. Butanol fermentation from microalgaederived carbohydrates after ionic liquid extraction. Bioresour Technol 2016;206:77-85.

99. Sharma A, Arya SK. Hydrogen from algal biomass: a review of production process. Biotechnol Rep 2017;15:63-9.

100. Patino R, Robledo D, Campo JSM. Production of microalgae biomass and biohydrogen in solar bioreactors. Bioenergy Technol 2011;17885 .

101. Wang J, Yin Y. Fermentative hydrogen production using pretreated microalgal biomass as feedstock. Microb Cell Factories 2018;17:2238.

102. Yun YM, Jung K, Kim D, Oh Y, Shin H. Microalgal biomass as a feedstock for bio-hydrogen. Int J Hydrog Energy 2012;37:15533-9.

103. Yang Z, Guo R, Xu X, Fan X, Luo S. Fermentative hydrogen production from lipid-extracted microalgal biomass residues. Appl Energy 2011;88:3468-72.

104. Nguyen TD, Kim K, Nguyen M, Kim D, Sim SJ. Enhancement of fermentative hydrogen production from green algal biomass of Thermotoga neopalitana by various pretreatment methods. Int $\mathrm{J}$ Hydrog Energy 2010;23:13035-40.

105. Roy S, Kumar K, Gosh S, Das D. Thermophilic biohydrogen production using pre-treated algal biomass as substrate. Biomass Bioenergy 2014;61:157-66.

106. Hwang J, Kim H, Choi J, Abou-Shanab RAI, Dempsey BA, Regan JM, et al. Photoautotrophic hydrogen production by eukaryotic microalgae under aerobic conditions. Nat Commun 2014;5:1-6.

107. Monlau F, Sambusiti C, Barakat A, Quéméneur M, Trably E, Steyer $\mathrm{JP}$, et al. Do furanic and phenolic compounds of lignocellulosic 
and algae biomass hydrolyzate inhibit anaerobic mixed cultures? A comprehensive review. Biotechnol Adv 2014;32:934-51.

108. Yun YM, Jung KW, Kim DH, Oh YK, Cho SK, Shin HS. Optimization of dark fermentative $\mathrm{H}_{2}$ production from microalgal biomass by combined (acid+ultrasonic) pretreatment. Bioresour Technol 2013;141:220-6.

109. Jeon BH, Choi JA, Kim HC, Hwang JH, Abou-Shanab RA, Dempsey $\mathrm{BA}$, et al. Ultrasonic disintegration of microalgal biomass and consequent improvement of bioaccessibility/bioavailability in microbial fermentation. Biotechnol Biofuels 2013;6(1):37-46.

110. Xia A, Cheng J, Ding L, Lin R, Song W, Zhou J, et al. Effects of changes in microbial community on the fermentative production of hydrogen and soluble metabolites from Chlorella pyrenoidosa biomass in semi-continuous operation. Energy 2014;68:982-8.

111. Xia A, Cheng J, Lin R, Lu H, Zhou J, Cen K. Comparison in dark hydrogen fermentation followed by photo hydrogen fermentation and methanogenesis between protein and carbohydrate compositions in Nannochloropsis oceanica biomass. Bioresour Technol 2013;138:204-13.

112. Buitrón G, Carrillo-Reyes J, Morales M, Faraloni C, Torzillo G. Biohydrogen production from microalgae. In: Microalgae-based biofuels and bioproducts. Elsevier, The Netherlands, pp 209-34, 2017.
113. Yoon JH, Shin JH, Kim MS, Sim SJ, Park TH. Evaluation of conversion efficiency of light to hydrogen energy by Anabaena variabilis. Int $\mathrm{J}$ Hydrog Energy 2006;31(6):721-7.

114. Xia A, Cheng J, Lin R, Lu H, Zhou J, Cen K. Comparison in dark hydrogen fermentation followed by photo hydrogen fermentation and methanogenesis between protein and carbohydrate compositions in Nannochloropsis oceanica biomass. Bioresour Technol 2013;138:204-13.

How to cite this article:

Tan KM, Harun R, Kamaludin R, Kassim MA. Microalgal biorefinery: Challenge and strategy in bioprocessing of microalgae carbohydrate for fine chemicals and biofuel. J Appl Biol Biotech 2021; 9(06):1-17 